\title{
An Overview of Foodpreneur Awareness among Small and Medium-Sized Enterprises (SME) of Halal Certification
}

\author{
Norngainy Mohd Tawil ${ }^{1,2}$, Shamshubaridah Ramlee ${ }^{1,3}$, Jauhari Jaafar ${ }^{1} \&$ Firdaus Mohd Saat $^{1}$ \\ ${ }^{1}$ Centre for Entrepreneurship and SMEs Development, Universiti Kebangsaan Malaysia \\ ${ }^{2}$ Faculty of Engineering and Built Environment, Universiti Kebangsaan Malaysia, Selangor, Malaysia \\ ${ }^{3}$ Faculty of Economics and Management, University Kebangsaan Malaysia, Malaysia \\ Correspondence: Norngainy Mohd Tawil, Faculty of Engineering and Built Environment, Universiti Kebangsaan \\ Malaysia, 43650 Bandar Baru Bangi, Selangor, Malaysia. E-mail: nmtawil@gmail.com
}

Received: April 17, 2015 Accepted: May 11, 2015 Online Published: July 6, 2015

doi:10.5539/ass.v11n21p91

URL: http://dx.doi.org/10.5539/ass.v11n21p91

\begin{abstract}
The objective of this study is to measure the awareness of Halal Certification among the Small and Medium-sized Enterprises (SME) especially those who are involved in the food industry. The study reveals that the awareness toward Halal Certification among Small-Medium Enterprise (SME) is at low level. But that raises a question mark when the study also indicates that the perceptions of the Muslim entrepreneur on halal food are very good.
\end{abstract}

Keywords: Halal certification, small medium enterprise, Muslim entrepreneur

\section{Introduction}

Food innovation remains a growth platform of a company. The innovation creates and provides opportunities for the company to remain relevant to survive in an atmosphere of intense business competition. Malaysia as a halal product manufacturer with Halal logo by JAKIM gained world recognition can provide product differentiation advantages to SMEs to explore international markets. Although various incentives have been provided, it is only utilized by companies that have established themselves in the business for a long time. Therefore, the SMEs also should not let themselves left behind. Furthermore, the government has given a lot of effort to make Malaysia as a halal food hub of the world, so the SMEs need to utilize this opportunity to upgrade their business (Arif, 2009).

According to Zulkifli Hasan (2008), halal products now have a very high demand due to population growth increasing among the Muslim population of 57 countries. It is estimated that by 2010 the Muslim population increased to three billion people by 2025 while the number rise to 30 percent of the total world population. Therefore, halal hub has attracted many countries such as Thailand, Singapore, and Philippines who are aware of the development of halal products. Other countries like the United States and Australia are also scrambling to take this opportunity to become producers of halal products (Nur Razuani Razali, 2010).

\section{Halal in Muslim Perspective}

Malaysia is a nation with Muslim are the majority, so the concept of halal is a big factor of consumption. Muslim consumers need to consume products and service from various, which somehow doubtful(Ambali $\&$ Bakar, 2012). When we talk about halal, it is not referring to food only, but also all matters of daily life.

This covers all aspects of human life and the dietary system without an exception. A Muslim is expected to ensure the legal status of any food before eating it. The "halal" food is the food that is permitted by Syariah for consumption while the forbidden one is "haram".

The standards developed by Department of Standards Malaysia have been recognized world wide (Talib et al., 2008). Whereas Bornne and Weber (2008) mentioned that the mechanism of halal quality must depends on the condition need to be followed as required for Muslim consumers.

\section{What Is Halal Food?}

According to Asyraf (2011) and Ahmad Nizam (2006), Syariah (Islamic law) has set a certain condition to be fulfill as halal food and most of food manufacturers need to appoint halal food committee to avoid misused of halal logo. 


\section{The Important of Halal Certification}

Halal Certification is the first step to expand the market for halal products to help consumers get products which is halal, safe and quality. (Ahmad Hidayat Buang et al., 2012). For micro and small enterprise that wants to penetrate the local market, effort to get Halal Certification status is something that is extremely difficult to achieve. The most common problem encountered is not to understand the demands of certification, which has resulted in this enterprise discontinue their desire to grow. They found that a claim or procedure is too complicated and requires high expenditure. Given that at least $80 \%$ of the food industry SMEs comprise Bumiputera enterprise where food is produced necessarily lawful, it is not fair if they are not motivated to get Halal Certification to expand their business.

Deputy Director of the Department of Islamic Affairs, Negeri Sembilan (JHEAINS), Ustaz Amran Awaluddin said, at present, more than half of the Halal Certificate holder consists of non-Bumiputera businessmen. According to him, this scenario shows the non-Muslim traders began to care for the needs of Muslim consumers of halal food and thus seize the opportunity to market their products more widely (Sinar Harian, 2013).

Fortunately, Ambali A. R. \& Bakar A. N. (2012) indicate that the introduction of halal logo and certification by (JAKIM) has generated more awareness among the Muslims on the importance of consuming manufactured products or engaging in services that follow Islamic guidelines and principles. JAKIM also would ensure all requirements stipulated under the MS 1500:2004 halal standards to be fulfilled before any halal product awarded a Halal Certificate (Quantaniah et al., 2013). Any product that awarded a Halal Certification is permitted to use Halal Logo in their label. Figure 1 show the Halal Logo which authorized by JAKIM.

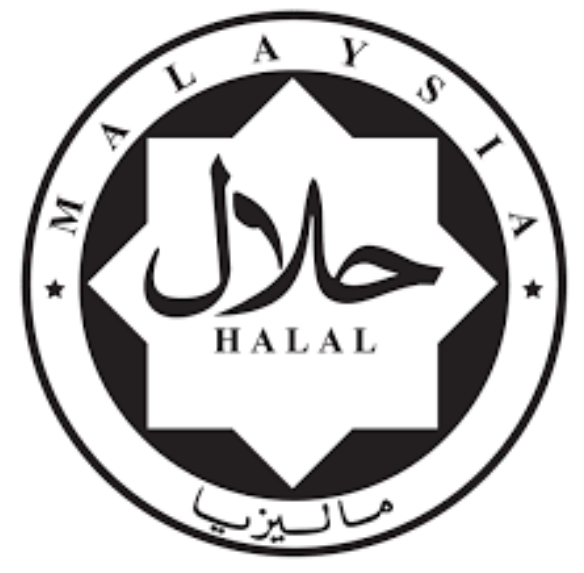

Figure 1

(Halal Malaysia, 2014)

\section{Halal Statistic in Malaysia}

\section{Halal Certified Company By Category of Industry}

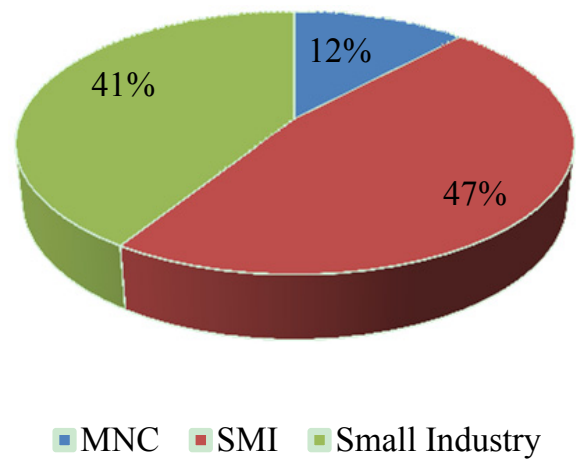

Chart 1 
Chart 1 above indicate that Small Medium Industry (SMI) have largest portion with $47 \%$ of the companies has been certified. Small Industry is the second with $41 \%$ and followed by Multinational corporations (MNC) with only $12 \%$.

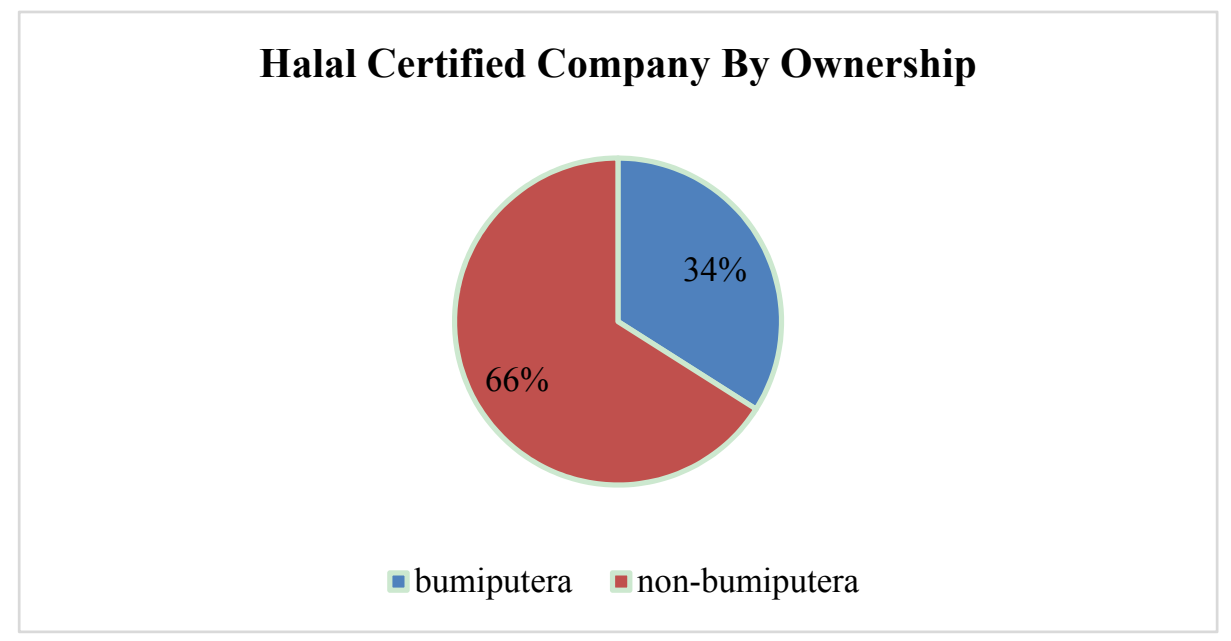

Chart 2

Chart 2 above indicates by all company which being certified by JAKIM, only $34 \%$ own by Bumiputera. Whereas another $66 \%$ of the companies are own by non-bumiputera (Halal Industry Development Cooperation, 2014).

\section{Conclusion and Recommendation}

The finding shows that awareness of small-medium enterprise (SME) toward Halal Certification is at low level. But the perceptions of the entrepreneur on halal food are very good .This is very disappointing because by understanding the important of Halal Certification in food industry will give SMEs a lucrative revenue. The potential of halal food industry was so big and will grow bigger by time. So, SMEs must take this opportunity to compete with others.

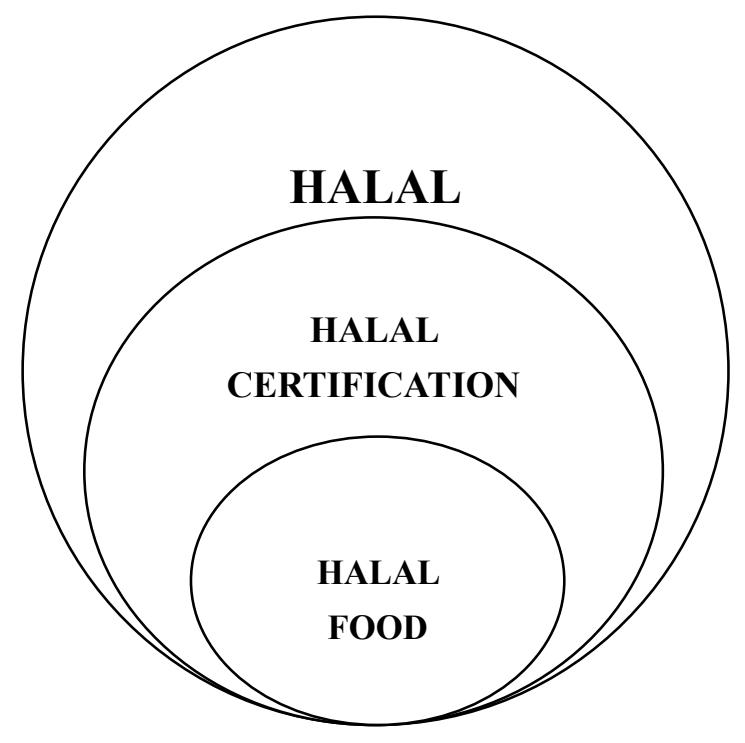

Figure 2 .

The Figure 2 shows that the concept of halal. Halal food is only part of Halal Certification. Where we can find that Halal Certification also apply for another products and services. For example like toothpaste, cosmetics and many more. Whereas, Halal Certification is only a tools to recognize the Halal products that comply with syariah. 
This is being support by Ismail F. R. \& Nasiruddin K. (2014) by saying that Malaysian consist of multiracial ethnic which if the food producer and supplier knows how to tackle the market creatively, it will help to boost company sales and brand positioning and future time and thus also promoting halal products widely.

Therefore, it is recommended that the government should take responsibility to organize series of campaign to give the SMEs knowledge and encourage them to get the Halal Certification. If the halal food industries in Malaysia are very serious to compete in the global market and to position Malaysia as Global Halal Food Hub, it must increase the numbers of Halal Certification holder.

\section{Reference}

Abdullah, A. N. B. (2006). Perception And Awareness Among Food Manufacturersand Marketers On Halal Food In The Klang Valley.

Ambali, A. R., \& Bakar, A. N. (2012). People's Awareness On Halal Foods And Products: Potential Issues For Policy-Makers. Universiti Teknologi MARA. http://dx.doi.org/10.1016/j.sbspro.2014.01.1104

Arif, S. (2009). Keupayaan Pemasaran dalam Kalangan Pengusaha Kecil Makanan Halal di Melaka Tengah: Satu Kajian Awal. Universiti Kebangsaan Malaysia.

Azeez, W. (2013). The Halal Dietary System as a Recipe for Good Health. IOSR Journal of Humanities and Social Science (IOSR-JHSS), 7(4), 28-34. http://dx.doi.org/10.9790/0837-0742834

Bonne, K., \& Verbeke, W. (2008). Religious Values Informing Halal Meat Production and the Control and Delivery of Halal Credence Quality. Agriculture and Human Values, 25(1), 35-47. http://dx.doi.org/10. 1007/s10460-007-9076-y

Buang, A. H., \& Mahmod, Z. (2012). Isu Dan Cabaran Badan Pensijilan Halal Di Malaysia. Shariah Journal, 20(3), 271-288.

Halal Industry Development Cooperation. (2014). Retrieved from http://www.hdcglobal.com/publisher/gwm industry_statistics

Halal Malaysia. (2014). Retrieved from http://www.halal.gov.my/v3/index.php/en/about-halal-certification/ halal-definition

Harian, S. (2013). Halal Awareness of Muslim Entrepreneurs.

Hasan, Z. (2008). Undang-Undang Produk Halal Di Malaysia: Isu Penguatkuasaan Dan Pendakwaan. Universiti Sains Islam Malaysia.

Ismail, F. R., \& Nasiruddin, K. (2014). Perception of Non-Muslim Consumers towards Halal Products in Malaysia FTMS College, Technology Park Malaysia. Bukit Jalil, Kuala Lumpur, Malaysia.

Quantaniah, N. A., Noreina, \& Syakinah, N. (2013). Selecting Halal Food: A Comparative Study of the Muslim and Non Muslim Malaysian Student Consumer. Faculty of Technology Management and Business, Universiti Tun Hussein Onn Malaysia, Malaysia.

Rahman, A. H. A. (2011). Knowledge on Halal Food amongst Food Industry Entrepreneurs in Malaysia. Universiti Malaysia Terengganu. http://dx.doi.org/10.5539/ass.v7n12p216

Razali, N. R. (2010). Kajian Ke Atas Potensi Sabah Sebagai Hab Halal. Universiti Malaysia Sabah.

Talib, A., Ali, M., Anuar, K., \& Jamaludin, K. R. (2008). Quality Assurance in Halal Food Manufacturing in Malaysia: A Preliminary Study.

\section{Copyrights}

Copyright for this article is retained by the author(s), with first publication rights granted to the journal.

This is an open-access article distributed under the terms and conditions of the Creative Commons Attribution license (http://creativecommons.org/licenses/by/3.0/). 